\title{
Corporate Social Responsibility Dilemma of Tiaka Oil and Gas Mining
}

\author{
${ }^{1}$ ILYAS LAMPE, ${ }^{2}$ HASLINDA B. ANRIANI, ${ }^{3}$ ANDI MASCUNRA AMIR \\ ${ }^{1}$ Department of Communication Studies, Faculty of Social and Political Sciences, Tadulako University, \\ Jl. Soekarno-Hatta Km. 9. Tondo, Palu, Indonesia, \\ 2,3Department of Sociology, Faculty of Social and Political Sciences, Tadulako University, \\ Jl. Soekarno-Hatta Km. 9. Tondo, Palu, Indonesia

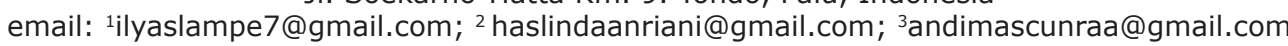

\begin{abstract}
The implementation of CSR programs of Tiaka refinery is based on financial, goods assistance, and several empowerment programs. However, the community's response is negative. The community's disappointment and dissatisfaction are accompanied by threats to the Tiaka refinery. This study uses a case study approach on Kolo Bawah, Baturube, and Tanasumpu to understand PT. Joint Operation Body (JOB) Pertamina Medco Tomori Sulawesi impacts on the loss of livelihood of the Bajo ethnic community in Kolo Bawah. The results show that the Bajo communities in Kolo Bawah are excluded from their living and cultural space because of the refinery. CSR activities and community empowerment are unable to reduce the economic and social burden of Bajo communities. CSR activities are not transparent, partial, and not accompanied by a needs assessment. CSR/CD activities remain as a source of mutual suspicion between regions, community and ethnic groups.
\end{abstract}

Keywords: CSR, oil and gas mine, bajo ethnic

\section{Introduction}

The main requirement for social activity and integration is the existence of social interaction within the community, dynamic interaction involving the relationship of individuals and between groups of people. This group will form a social community that performs its functions in accordance with existing norms and rules (Verbeke, 2010).

The Bajo community is a community in the Kolo Bawah area in Morowali. The Kolo Bawah area is an area with potential for petroleum; this makes Kolo Bawah the closest location and settlement to the offcoast oil refineries. The Bajo community is the party that fights for the attention and fate of the village community whose majority work as fishermen. The marker of the dark period of the Kolo Bawah village community began when the Bajo community movement demanded the oil refinery drilling company PT. Job PMTS (Joint Operation Body Pertamina-Medco Tomori Sulawesi) for the activities carried out by the company and the increasingly excluded people from their living space and cultural space (Mallet et al., 2015).

Kolo Bawah village, known as a coastal village, has a population of up to 1,300 people, located directly opposite Tolo Bay where PT. Job PMTS (Joint Operation Body of Pertamina-Medco Tomori Sulawesi) is located; the location is later more known as the Tiaka Oil Refinery. This Bajo ethnic village is 12 miles from the Tiaka refinery and is the closest village along the coastline to the location of the refinery. Most of the villagers in Kolo Bawah are fishermen.

For the Bajo community in Kolo Bawah, the discourse on oil and gas is new as the existence of oil and gas exploration in Tiaka started in 2004 (Hermanto, 2015). Tiaka is a group of coral which was later reclaimed as an island where the oil and gas refinery of PT. JOB PMTS. Since then, the residents of Kolo Bawah have been accustomed to discourse about oil and gas. Profit-sharing

Received: 2019-09-18, Revised: 2019-10-23, Accepted: 2019-12-27

Print ISSN: 0215-8175; Online ISSN: 2303-2499. DOI: https://doi.org/10.29313/mimbar.v35i2.5143

Accredited Sinta 2 based on the decree No.10/E/KPT/2019 until 2024. Indexed by DOAJ, Sinta, Garuda, Crossreff, Dimensions 
funds, Corporate Social Responsibility (CSR), community development, joint operation bodies, SKK Migas and other terms (Arora \& Dharwadkar, 2011; Carroll \& Shabana, 2010). Since then, the hope of a new era of prosperity has been marked by the burning fire of oil left which light on the coast of Tolo bay, whose light is seen at the homes of residents in Kolo Bawah.

The fact presented in the field, by the oil and gas company PT. Job PMTS, so far the company is considered to have exploited oil in Tiaka and as a cause of poverty in Kolo Bawah. For the Bajo in Kolo Bawah and its surroundings, Tiaka is the most promising fishing ground for marine products. It has the abundant potential of marine products and would be able to prosper the surrounding communities who work as fishermen. Sapa mataha (regional language for Tiaka) which is more or less the longest base, which Bajo ethnic groups have used as fishing grounds for decades can no longer be accessed. The cluster of coral reefs was once considered the largest fish nest because it was very rich in marine products, such as Napoleon Wrasse (Cheilinus undulatus), Sea Cucumber, Lobster, Octopus, Sea Shells, and Giant Kima shellfish (Tridcna Spp). Throughout the year, fishermen are very dependent on marine resources in the Tiaka region (Sangadji, 2011). However, in fact, the companies do not allow fishermen from anywhere to reach a radius of $1 \mathrm{~km}$ from the Tiaka oil and gas refinery. They will be driven back by the security forces of the company or the police officers who are assigned to the installation if anyone approaches.

The closed access point makes the Bajo tribe in Tiaka raises various demands on companies aiming at getting the restitution of residents' income lost due to the existence of the Tiaka oil and gas mine in the form of job opportunities, local business opportunities, and most importantly, the demand for corporate social responsibility (CSR). CSR is actually an investment obligation, which must be started since there is an activity in the area predicted to be affected (Lampe, 2015). However, the contents of Corporate Social Responsibility are very strong as the participatory level decreases in practice to serve the community in the era of globalization and the participation of various sectors, especially the corporate sector in preserving civil society (Djajadikerta \& Trireksani, 2012). CSR is not only understood as an activity carried out after a company makes a profit, especially if these activities have an impact on the environment and socio-culture from the outset. In the context of this research, the offshore oil and gas mining area of PT. Job PMTS which is located in Karang Tiaka, is not carrying out the function of Corporate Social Responsibility as a part of the company, after the company took over the area of Bajo's livelihood. Bajo people cannot visit the area and the company does not provide a solution to this problem. The company has not yet conducted coordination with related parties to resolve and provide a way out for the community.

There are no community empowerment activities and stakeholder cooperation in this area and the company tends to ignore that (Frederiksen, 2018b). The area was originally a source of community livelihood, and then through reclamation, the government allows the company to carry out its activities. However, the company is not properly conducted its CSR obligation which triggers ceaseless bad responses from people of Kolo Bawah neighborhood and Bajo community from year to year. CSR cannot only be seen as an effort to share profits but a substitute for disrupting people's lives. The social responsibility that should be carried out by the company towards the implementation, development, and sustainability of the community related to concepts and mechanisms in the world of work is only seen as voluntary or generosity so that many people do not feel the real benefits (Frederiksen, 2018a; Majer, 2013; Wijaya, 2012).

Based on the background above, this article will explore how the implementation of the Corporate Social Responsibility of PT. Job PMTS in the Bajo ethnic community in Kolo Bawah, Morowali Utara Regency, is related to the location of reclamation which is a source of the community economy.

More specifically, CSR defined as a situation where the company goes beyond compliance and in actions that appear to further some social good, beyond the interest that is required by law (Rahman, 2009). CSR, in general, can be understood as an attempt by the company to balance economic, environmental, and social needs or goals (Arora \& Dharwadkar, 2011). On the other hand, it can also fulfill the wishes of shareholders and stakeholders. In other words, CSR is how companies can interact with shareholders, employees, customers, 
suppliers, government, NGOs, and other stakeholders.

From a corporate perspective, CSR is a process of internalizing external factors (the internalization of externalities) that refers to the Triple Bottom Line (3P), namely people, planet, and profit. A good company not only pursues economic profit but also concern about environmental preservation (planet) and people's welfare (people) (Nasdian, 2014). Furthermore, the process and implementation of CSR can be identified into seven issues: 1) Organizational government; 2) Human rights; 3) Labor practices; 4) Environment; 5) Fair operating practices; 6) Consumer issues; and 7) Community development (Nasdian, 2014). The Triple Bottom Line is used so that the company can try to minimize the impact and loss on the environment while still being able to increase the economic needs and have a positive impact on society (Melles, de Vere, \& Misic, 2011). In carrying out the company's operations and increasing a profit in terms of the economy, a corporation should be able to make a positive contribution to the community and its environment. Responsibility for the impacts that will occur from a company's decision regarding activities to the community and the environment can be realized transparently and ethically along with the sustainability and welfare of the community.

The process of development and social responsibility carried out in the community are based on community development contributions, funding activities in accordance with the illegal framework, community participation in business, and responses to the pressure from interest groups (Madumere, 2017; Shi a, 2012). The World Business Council for Sustainable Development discusses CSR as a company commitment in order to build and contribute to the economy in a sustainable manner. The form of participation in the world of sustainable business is to build and develop corporate awareness programs for the surrounding community. In terms of community and broader Society, activities of the majority of companies through community empowerment are essentially about how individuals, groups or communities that try to implement community empowerment through various development projects that enable members and the community to obtain support in fulfilling the community needs.

There are three main things that are commonly understood regarding CSR: first, a voluntary role in which a company helps to overcome social and environmental problems, therefore the company has free will to do or not do this role; second, aside from being a profit institution, the company set aside a portion of its profits for philanthropy which aims to empower social and improve environmental damage due to exploration and exploitation; third, CSR is a form of obligation for companies to care about and alleviate a growing humanitarian and environmental crisis (Marnelly, 2012).

Particularly in mining CSR studies, CSR is labeled with the term "devil may care" (reckless or unconcerned) to describe the pattern of mining operations, especially in the oil and gas industry (Jenkins \& Obara, 2008). This is related to the fact that often the oil and gas industry operates in an area without legitimacy, causes great damage, and then leaves the former operational area after economically valuable sources run out. However, in recent years, the mining industry globally has shown concern in handling social and environmental responsibilities.

Many factors have contributed to this, where extractive industries are the key to debate about social and environmental sustainability (Jenkins \& Obara, 2008). The CSR program in the mining sector tends to focus more on local community initiatives that have an impact on the economic, social, and environmental sectors with a great benefit at the local level. However, the effectiveness of CSR initiatives of the oil and gas sector and mining has raised more questions (Frynas, 2009). While multinational mining companies have "transformed" themselves into "as good corporate citizens" with little evidence to gain recognition to address sustainability issues.

To be in a sustainable and balance system, the company cannot stand alone. Indirectly, the existence of companies influences various social, economic, and cultural life of the surrounding community. The company will interact directly or indirectly with the community. The socio-cultural is one of the most important aspects, considering that the CSR program is intended to foster good relations among stakeholders in relation to the organizers of corporate CSR so that there are reciprocal good relations with other stakeholders, government, private sector, and various levels of society elements. Indeed, in the mining industry, the main stakeholders are "communities", which is why the initiative towards CSR implementation is so focused and 
strong. Actually, mining has a large positive impact on local communities including the creation of new communities and the growth of wealth, export revenues and royalties, transfer of technology, the increasing number of skilled and trained workers from the local population, infrastructure improvements such as roads, schools, and health clinics (Jenkins \& Obara, 2008).

A more interesting study was conducted by Benedict $Y$. Imbun as outlined in an article titled "Can Not Manage Without "Significant Other": Mining, Corporate Social Responsibility and Local Communities in Papua New Guinea" (Imbun, 2007). This study also provides important learning lessons for social learning and responsibility which shows that CSR is only used as an effort to reduce community action and social resistance to the existence of the mining. CSR by companies is considered to be able to solve social problems arisen in the local community and assume that the existence of the company has provided great benefits to the local community. Such a view, CSR oriented, causes companies to lose solutions to social problems and conflicts that occur when local communities show resistance to the existence of companies. As a result, one of the pressing factors that continue to emerge in two mining areas in Papua New Guinea is local communities where they demand the empowerment of local communities, especially through CSR programs, which the company simply ignores.

Currently, the responsibility of corporate is not only based on the single bottom line but also the company must be able to reflect or rest on the triple bottom line which covers the financial, social, and environmental aspects of the company (Kusumadilaga, 2010). This is because if a company is only based on a single sector, it will not guarantee that it will become a sustainable increase in the value of the company. Thus, the company is expected to be able to harmonize the three dimensions based on the recommendation of the Global Reporting Initiative in order to be able to communicate its accountability to stakeholders.

\section{Research Methodology}

This study used a qualitative interpretative based case study approach to understand real-world cases in contemporary contexts through various data sources (Cresswell, 2014; Yin, 2014). This study focused on the ethnic communities around the gas and oil mining operations area as the main source of data. The informants are public figures in Kolo Bawah, Baturube and Tanasumpu Village; customary leader of Bajo ethnicity in Kolo Bawah; community leaders and youth figures that actively involved in the gas and oil mining operations in Tiaka. Initial observations are done from 2016 to 2017 in the most affected villages around the operation area through deep interviews with the aforementioned informants. The collected data also enriched with the data from the document study in the form of news archives and annual reports. Collected data then categorized into separate groups to be analyzed and interpreted before it was being concluded.

\section{Results and Discussion}

\section{Between Company and Community: The Basis of CSR Program Implementations}

The initial observation and compiled interviews with community leaders, especially with the customary leader of Bajo ethnicity in Kolo Bawah, showed that many CSR activities have been carried out since the existence of the company in Tiaka, both during the exploration period and exploitation period, although they referred to as a variety of assistance to the local community. The absence of institutionalization of CSR activities at the initial stage, namely the exploration and construction stages has led to activities that are actually included in the realm of CSR activities only referred to as "assistance". Various types of assistance are channeled through company representatives in mine-circle villages called company public relations or company spokespersons. These "companies" are community leaders who are often vocal and are an extension of the company in the villages around the mine, whose functions can be various, either public relations or be "company spies".

JOB Pertamina Medco E-P Tomori Sulawesi published a track record titled "Together with the Community to Build Banggai and Morowali". In this 2012 track record, the company does not even use the term comdev, CD funds, or CSR funds, but various activities e.g. assistance (funds, goods), training program (training provided by the company). Since the exploration-exploitation stage, the company has allocated a number of 
programs and assistance to the communities in the villages around the Tiaka Oil Field, which includes Community Empowerment Program, Health and Environment Program, Infrastructure Assistance Program, Sports Facility, and Education Program, Religious Participation Program and Training Program (Women and Children) (JOB PMTS, 2015). However, the voice of the public regarding CD/ CSR/Comdev funds and company assistance programs in these villages was largely ended with expressions of disappointment, dissatisfaction, injustice, and even the demands that were accompanied by threats.

When being interviewed, public figures in Kolo Bawah, Baturube, and Tanasumpu Village were agreed that the CSR seems incidental, very limited, and not wellprogrammed. The lack of coordination and non-institutionalization of CSR activities made the programs less known by the surrounding communities. Whereas, PT. JOB PMTS provided funds for revamping public and social facilities and also direct cash assistance provided by companies but were not recorded, documented and covered enough by the media.

Furthermore, community leaders of Kolo Bawah, Baturube and Tanasumpu also stated that the assistance provided by the company to local residents is quite a lot. For example, in 2007, the company provided 10 pieces of Katinting boat for each Ring 1 village. In the social sector, mosque renovation and food assistance for residents are provided at Eid al-Fitr and Eid al-Adha celebrations. In 2010, CSR funds were also channeled to 14 villages in Mamosalato worth five hundred million rupiahs. While the empowerment program of the Bajo fishermen in Kolo Bawah has been carried out since 2011 such as seaweed cultivation, snapper cages, lobster cultivation, and other empowerment programs (Hsbl, 30 years old, interviewed in July 2016).
Since the end of 2013, along with the institutionalization of Comdev activities in a division, various empowerment programs have been launched as it was contained in the 2014 Annual Report Community Development which covered the operational areas of JOB PMTS both in the Sinorang and Tiaka blocks (JOB PMTS, 2015). In the report, it was explained that the programs implemented sought to improve alternative community livelihoods through training for skills improvement. From a total of 27 types of programs and more than 40 sub-activities, there were three empowerment programs that were a mainstay, namely catfish cultivation, organic farming, and herbal medicines. While the livelihood activity that characterizes the community development in PT. JOB PMTS is the cultivation of soft shell crabs (JOB PMTS, 2016).

Other programs carried out in the 2014 period in the Tiaka block operational area include catfish farming in Tanasumpu Village; making the VCO (virgin coconut oil) and herbal medicines in Tambale, Pandauke, Tananagaya, Kolo Bawah, Kolo Atas, Tambarobone and Baturube; welder training attended by 18 people from Bungku Utara at the Palu Training Center; sewing and embroidery training attended by 20 people from Mamosalato.

Meanwhile, if summarized as a whole, the programs implemented in the Tiaka block operational area during the period of the end of 2013 to 2015 include empowerment of the Kolo Bawah community through fish cage cultivation with a budget of Rp 900,538,000; provision of $2500 \mathrm{Kva}$ power generators intended for Kolo Atas and Kolo Bawah

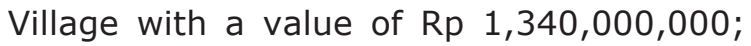
the construction of a Power House in Kolo Bawah with a budget of Rp. 5,081,888,000; and independent electricity supervision in Kolo Bawah Village with a budget of Rp. $289,300,000$. Some programs included

Table 1

CD/CSR Program Budget and Realization in 2014

\begin{tabular}{lrr}
\hline \multicolumn{1}{c}{$\mathbf{2 0 1 4}$} & \multicolumn{1}{c}{ PROGRAM } & \multicolumn{1}{c}{ ACTUAL } \\
\hline Charity & $935,000,000$ & $770,105,080$ \\
Infrastructure & $6,576,000,000$ & $3,464,751,181$ \\
Capacity Building & $940,000,000$ & $515,834,000$ \\
Empowerment & $2,980,000,000$ & $2,841,198,729$ \\
Total & $11,431,000,000$ & $7,591,888,990$ \\
\hline
\end{tabular}

Source: CD Annual Report of PT. JOB PMTS (JOB PMTS, 2015) 
Table 2

CSR/CD JOB PMTS Budget Realization in the Last 5 years

\begin{tabular}{lrrrrrr}
\hline Year & \multicolumn{1}{c}{ Charity } & Infrastructure & Capacity Building & Empowerment \\
\hline 2011 & $\$ 115,348.00$ & $\$ 99,648.00$ & $\$$ & $66,030.00$ & \\
2012 & $\$ 47,347.00$ & $\$ 289,438.00$ & $\$$ & $13,052.00$ & $\$ 87,516.00$ \\
2013 & $\$ 38,447.32$ & $\$ 508,488.43$ & $\$$ & $56,570.36$ & $\$ 362,061.86$ \\
2014 & $\$ 143,076.93$ & $\$ 603,692.30$ & $\$$ & $96,410.26$ & $\$ 492,820.53$ \\
2015 & $\$ 12,500.00$ & $\$ 91,666.66$ & $\$$ & $37,499.00$ & $\$ 205,416.60$ \\
\hline
\end{tabular}

Source: 2015 Annual Report of CD (JOB PMTS, 2016)

recommendations from the National Human Rights Commission as a result of the Tiaka conflict which killed two residents of Kolo Bawah. Table 1 shows the number of funds allocated and the realization for CSR and Comdev activities in the Senoro and Tiaka regions in 2014.

The budget used in 2015, as conveyed by Field Public Relations of JOB PMTS, came from two sources, namely cost recovery with a proportion of $49 \%$ and $51 \%$ of non-cost recovery funds and additional funds from the remaining of 2014. In 2015, planned programs included infrastructure activities carried out in collaboration with third parties so that budget absorption was getting better. The budgetary data of CSR and CD activities allocated by JOB PMTS in the area around the Senoro-Tiaka block during the period of 2011 to 2015 are presented in Table 2 .

Based on data on the amount of the budget allocated for CSR and CD activities in the area around the project, the amount was quite large with a fairly good variety of programs. In fact, the substantial funds have not had a direct impact on the welfare of the local community, especially in the ring 1 area of the Tiaka block in Kolo Bawah. In both villages, many empowerment programs were implemented but failed because they were not sustainable. In Kolo Bawah, for example, snapper cultivation in cages has been carried out in 2 stages of the program based on the second phase of program data from 2014 to 2015 costing Rp. 900,538,000 but it was not sustainable. According to Ade Aling (50 years old, interviewed in January 2017), the yield from the seedlings provided by the company was quite successful, but the harvest was not directly allocated to capital expenditure (snapper seeds) but was shared to the group members so that for further maintenance the seeds could no longer be bought. In the end, the program with a quite large budget was hampered again. Ade further stated that it was hard to put the Bajo people of Kolo Bawah in a group since they like to suspect each other so that programs with group characteristics are difficult to last long.

\section{Community Development Based on CSR Programs}

According to Hsbl (30 years old, interview in July 2016), almost all CSR activities have been at the request of community members through groups formed or proposals submitted by educational, health, and social institutions. This condition causes inequality in groups of people who do not have the expertise to make proposals that comply with JOB standards. Most CSR and CD funds can only be accessed by educated citizens and groups they formed. The elite educated people then turned into agents who mediated with the company; most of these roles were carried out by village officials, sub-districts and school teachers.

Based on the results of field research, CSR and Com dev activities carried out by JOB PMTS around its operational areas, both in the Ring I and Ring 2 areas that have only been effective since 2014 . This assessment is effective by, at least, viewing at aspects of program planning, implementation, and evaluation. On the implementation side, CSR activities are directed at community development programs under the control of the Community Development Section that established since the end of 2013 and effectively carry out assistance in early 2014. Likewise, on the evaluation, CSR activities have been carried out with the comdev division cooperation.

Since the operation of JOB PMTS in Tiaka which began in 2005, CSR activities have been carried out incidentally based on the leadership's requests and policies. Even in a period of several years, according to some informants, there were almost no CSR activities were carried out by the 
company. Local people's perceptions of the company are increasingly negative as their economic life becomes more difficult. The loss and disruption of fishermen's livelihoods around the Tiaka oil and gas mining are not accompanied by income restitution through JOB PMTS assistance. In this stage, a change in CSR policy of Tiaka refinery is crucial. CSR itself is an adaptable conceptual paradigm. Thus, the shift of communities' view of the CSR programs of Tiaka refinery should be deciding point on how CSR would be implemented to adapt with the current and foreseen condition and to enact an improvement and sustainable plan (Latapí Agudelo, Jóhannsdóttir, \& Davídsdóttir, 2019).

As aforementioned before, CSR is a process of internalizing external factors that refers to the people, planet, and profit. Thus, the existence of CSR is a concern for environmental preservation and people's welfare (Nasdian, 2014). The CSR programs of Tiaka refinery, in the context of local residents, were deemed unsustainable. It has caused the residents of fishermen in Kolo Bawah to feel the direct impact of Tiaka's coral exclusion. The declining income of fishermen, especially in Kolo Bawah where the social movement is the strongest, is proof that even if there is equipment aid for fishermen, the fact that the fishing areas were reduced has bigger impacts. This finding clearly shows that the companies' CSR programs and the implementation are not socially and environmentally sustainable as the livelihood of the fishermen become more increasingly difficult as opposed to being focused on the social and environmental sustainability program (Jenkins \& Obara, 2008).

\section{The Complexities and Failures of CSR Implementation}

Based on the process and historicity of the implementation of PT Job PMTS' CSR around the Tiaka oil and gas mining, the complexity of the problem can be mapped both from managerial aspects as well as of the community aspects. From the managerial aspects, the failure of the implementation of CSR of Job PMTS is partly due to: first, CSR activities funds are included in the cost recovery section which means that the funds are charged to the state so that implementations are more "complicated" in their management. Second, CSR activities aimed at community development efforts from 2005 to 2011 were not preceded by comprehensive need assessment so that there was no match between the programs implemented and the needs of the community. Third, Job PMTS, in this case, personal in charge of CSR/CD activities does not comprehensively comprehend the local culture of the residents; for example, arranging fishermen empowerment programs with the cultivation of seaweed, snapper, and lobster in Kolo Bawah without long term assistance even though the Bajo are culturally captured fishermen, not cultivated fish farmers. Fourth, the division institutionalization that handles Comdev has only been formed in the Job PMTS structure since the end of 2013 so that CD-based CSR implementation is carried out at a minimum. Fifth, the management of corporate communications is very poor. Internally, the public relations and PIC CD divisions do not coordinate and support each other so that each front line of communication has its own line.

On the side of the local community, there are some research findings on the cause of the failure of CSR implementation in Tiaka: first, local Bajo ethnic groups find it difficult to be in a group and collaborate. They tend to suspect each other in terms of managing the empowerment activities. It is compared to ex-transmigrants who received the same assistance from CSR Job PMTS activities which was far more successful and sustainable. Second, local ethnic groups always hope that the form of assistance distributed by companies is in the form of cash, whereas Pertamina's CSR activities are not justified in cash. Third, there are misperceptions by local residents regarding CSR funds which are often considered the profit-sharing funds (DBH) whose budget management through local governments.

The complexity of the governance of CSR activities in the mining industry as illustrated in the pattern of relationships that are intertwined in this business, namely the number of parties involved and the magnitude of social and environmental risks caused. Nevertheless, the failure of the implementation of CSR is not merely a matter of governance but one of the most important is the commitment to develop local communities. It seems that PT Job PMTS from the beginning did not realize the importance of managing CSR as part of its commitment to the community but was only placed as part of the "license to operate" to obtain permission to exploit or to gain social acceptance of its business (Prayogo, 2010). Whereas, in fact, 
social responsibility as a humanitarian and environmental commitment will guarantee the sustainability of the company's operations until the end of the contract period.

In mining companies, CSR is a manifestation to become larger and as a practical implementation of sustainability goals (Jenkins \& Obara, 2008). CSR is the company's means of framing attitudes and strategies towards relationships with stakeholders, investors, employees, and communities as a popular and acceptable concept. In the mining industry, progress in three dimensions of sustainable development (economic, environmental, and social) can be achieved through economic development (income investment generated to ensure future development and long-term livelihoods of the community); environmental protection (minimizing the environmental impact of exploitation of natural resources and rehabilitation of land to allow further use); and social cohesion by reducing social and cultural disturbances for the community, maintaining dialogue with stakeholders, and transparency in operational activities (Fadel, Zabidi, \& Ariffin, 2016).

The findings of the research show a tendency that CSR activities were initially used only as a means/tool to reduce community social action and resistance. Massive protests and social movements that led to the loss of life of local communities then made the company aware of the importance of CSR as a social commitment to the exclusion of the Tiaka region that was the source of life for local communities. The company built an assumption that CSR can solve all the problems of the local community so that they have difficulties in finding the 'real solution' to the problem of the local community's resistance. This is in line with what was found by Imbun (2007) in gold mining in Papua New Guinea which showed that the relations between corporations and communities were so bad that local ethnicities are marginalized. This "silencing" focused CSR implementation showed that CSR programs of Tiaka refinery are focused more on the social side. For comparison, many firms in Bolivia did the opposite as they were leaning more towards environmentally-focused CSR programs (Herbas Torrico, Frank, \& Arandia Tavera, 2018). While the Tiaka refinery is more into socially-focused CSR, albeit only "only fulfilling obligation" to reduce community social action and resistance without proper ethical and sustainable behavior.
The CSR governance model and communication patterns built by the company caused tensions between communities. Affected social status, budget allocation issues, implementation approaches. and locations selection for implementing CSR have caused mutual suspicion and lead to violence. It is because, for local communities around Tiaka, CSR instead becomes a solution to the problem of marginalization, loss of livelihood, and the closure of access to resources which is a source of new conflicts (Lampe, 2015). The marginalization and other social problems are not in line with what Kusumadilaga (2010) defined, as the company did not cover the social aspects. For this kind of impact alone, CSR needs to be properly regulated and controlled. CSR implementation of Tiaka refinery, especially in the early stage, is an example of "only fulfilling obligation" kind of activities. This kind of mentality should not be applied in handling CSR since CSR is not only just an obligation, but also a sustainable necessity and can be strategically used to induce better company performance through effective and efficient CSR communication (Mitra, Akhtar, \& Gupta, 2018).

\section{Conclusions}

The implementation of CSR in Tiaka oil and gas mining became a form of restitution for the reduction or loss of livelihood of fishermen in surrounding communities, especially the Bajo ethnicity of Kolo Bawah village. Tiaka's reef exclusion has gradually eliminated the access of local communities to their livelihoods which has been hereditary fishing ground for fishermen in Kolo Bawah and it's surrounding areas. Efforts to improve CSR activities and their management are actually carried out by the management. The improvement efforts are proven by the institutionalization of more community development-oriented (CD) CSR programs since 2013. CSR activities are no longer based solely on community demand but also from compiled assessment results by independent institutions. However, instead of experiencing improvements in the social situation of the community that is already resistant to the company, CSR is often considered the source of new conflicts. The weak determining efforts of the affected area, bad activities location establishment, and improper patterns of engagement are sources of jealousy between regions and between groups. The violence accident that caused 2 fatalities in 2011 
is evidence that cannot be denied for the failure of CSR management to the affected community. Thus, PT. JOB PMTS should put CSR/Comdev not only as part of an effort to expedite the company's operations, but also the responsibility of humanity.

\section{References}

Arora, P., \& Dharwadkar, R. (2011). Corporate Governance and Corporate Social Responsibility (CSR): The Moderating Roles of Attainment Discrepancy and Organization Slack. Corporate Governance: An International Review, 19(2), 136-152. https://doi.org/10.1111/ j.1467-8683.2010.00843.x

Carroll, A. B., \& Shabana, K. M. (2010). The Business Case for Corporate Social Responsibility: A Review of Concepts, Research and Practice. International Journal of Management Reviews, 12(1), 85-105. https://doi.org/10.1111/j.14682370.2009.00275.x

Cresswell, J. W. (2014). Penelitian Kualitatif \& Desain Riset: Memilih di Antara Lima Pendekatan (Terjemahan). Yogyakarta: Pustaka Pelajar.

Fadel, M. A. M., Zabidi, H., \& Ariffin, K. S. (2016). Monitoring the Quarry Pit Development. Procedia Chemistry, 19, 721-728. https://doi.org/10.1016/j. proche.2016.03.076

Frederiksen, T. (2018a). Corporate social responsibility, risk and development in the mining industry. Resources Policy, 59(March), 495-505. https://doi. org/10.1016/j.resourpol.2018.09.004

Frederiksen, T. (2018b). Political settlements, the mining industry and corporate social responsibility in developing countries. Extractive Industries and Society, (March), 0-1. https://doi.org/10.1016/j. exis.2018.07.007

Frynas, J. G. (2009). Corporate social responsibility in the oil and gas sector. The Journal of World Energy Law \& Business, 2(3), 178-195. https://doi.org/10.1093/ jwelb/jwp012

Gery Djajadikerta, H., \& Trireksani, T. (2012). Corporate social and environmental disclosure by Indonesian listed companies on their corporate web sites. Journal of Applied Accounting Research, 13(1), 21-36. https://doi. org/10.1108/09675421211231899

Herbas Torrico, B., Frank, B., \& Arandia Tavera, C. (2018). Corporate social responsibility in Bolivia: meanings and consequences. International Journal of Corporate Social Responsibility, 3(1), 1-13. https://doi. org/10.1186/s40991-018-0029-0

Hermanto, B. (2015). Usulan Baru Titik Bor Eksplorasi Minyak Dan Gas Bumi Di Lapangan Tiaka Dan Senoro, Cekungan Luwuk-Banggai. Jurnal Geologi Dan Sumberdaya Mineral, 16(1), 4553. https://doi.org/http://dx.doi. org/10.33332/jgsm.geologi.16.1.45-53

Imbun, B. Y. (2007). "Can not manage without the "significant other": Mining, corporate social responsibility and local communities in Papua New Guinea. Journal of Business Ethics, 73(2), 177-192.

Jenkins, H., \& Obara, L. (2008). Corporate Social Responsibility (CSR) in the Mining Industry - The Risk Of Community Dependency. Retrieved July 14, 2018, from semanticscholar.org website: https://www.semanticscholar.org/paper/ Corporate-Social-Responsibility-(CSR)-inthe-mining-Jenkins-Obara/8e9765f4eecd 8d51854d6c58171e0c2208c83f28

JOB PMTS. (2015). Annual Report CD Job PMTS 2014.

JOB PMTS. (2016). Annual Report CD Job PMTS 2015.

Kusumadilaga, R. (2010). Pengaruh Corporate Social Responsibility Terhadap Nilai Perusahaan dengan Profitabilitas Sebagai Variable Moderating. Universitas Diponegoro.

Lampe, I. (2015). Berebut Akses Ekonomi dan Tuntutan Implementasi Corporate Social Responsibility (CSR) pada Tambang Migas Tiaka, JOB Pertamina-Medco, Morowali Utara, Sulawesi Tengah. Prosiding Konferensi Nasional Komunikasi ISKI. Solo.

Latapí Agudelo, M. A., Jóhannsdóttir, L., \& Davídsdóttir, B. (2019). A literature review of the history and evolution of corporate social responsibility. International Journal of Corporate Social Responsibility, 4(1), $1=23$. https://doi.org/10.1186/s40991018-0039-y

Madumere, N. (2017). Public enlightenment and participation - A major contribution in mitigating climate change. International Journal of Sustainable Built Environment, 6(1), 9-15. https://doi.org/10.1016/j. ijsbe.2016.10.003

Majer, M. (2013). The Practice of Mining Companies in Building Relationships with Local Communities in the Context of CSR Formula. Journal of Sustainable Mining, 12(3), 38-47. https://doi.org/10.7424/ 
jsm130305

Mallet, M., Dulac, F., Formenti, P., Nabat, P., Sciare, J., Roberts, G., ... Zapf, P. (2015). Overview of the Chemistry-Aerosol Mediterranean Experiment/Aerosol Direct Radiative Forcing on the Mediterranean Climate (ChArMEx/ADRIMED) summer 2013 campaign. Atmospheric Chemistry and Physics Discussions, 15(14), 1961519727. https://doi.org/10.5194/acpd-1519615-2015

Marnelly, T. R. (2012). Corporate Social Responsibility (CSR): Tinjauan Teori Dan Praktek Di Indonesia. Jurnal Aplikasi Bisnis, 3(1), 49-59.

Melles, G., de Vere, I., \& Misic, V. (2011). Socially responsible design: thinking beyond the triple bottom line to socially responsive and sustainable product design. CoDesign, 7(3-4), 143-154. https://doi.org/10.1080/15710882.201 1.630473

Mitra, N., Akhtar, A., \& Gupta, A. Das. (2018). Communicating Corporate Social Responsibility in the post mandate period: Evidence from India. International Journal of Corporate Social Responsibility, 3(1), 1-16. https://doi.org/10.1186/s40991018-0033-4

Nasdian, F. T. (2014). Pengembangan
Masyarakat. Jakarta: DSKPM Fakultas Ekologi Manusia IPB - Yayasan Pustaka Obor Indonesia.

Prayogo, D. (2010). Anatomi Konflik antara Korporasi dan Komunitas Lokal pada Industri Geotermal di Jawa Barat. Makara, Sosial Humaniora, 14(1), 25-34.

Rahman, R. (2009). Corporate Social Responsibility; Antara Teori dan Kenyataan. Jakarta: Buku Kita.

Sangadji, A. (2011, September 26). Penembakan Tiaka dan Akumulasi Primitif. Indoprogress.

Shi a, H. Q. (2012). Mine Green Mining. Energy Procedia, 16, 409-416. https:// doi.org/10.1016/j.egypro.2012.01.067

Verbeke, A. (2010). International acquisition success: Social community and dominant logic dimensions. Journal of International Business Studies, 41(1), 38-46. https:// doi.org/10.1057/jibs.2009.70

Wijaya, M. (2012). Faktor-Faktor yang Mempengaruhi Pengungkapan Tanggung Jawab Sosial pada Perusahaan Manufaktur yang Terdaftar di Bursa Efek Indonesia. Jurnal Ilmiah Mahasiswa Akuntansi., 1(1), 26-30.

Yin, R. K. (2014). Studi Kasus Desain dan Metode. Jakarta: Raja Grafindo Persada. 